\title{
COP1 Gene
}

National Cancer Institute

\section{Source}

National Cancer Institute. COP1 Gene. NCI Thesaurus. Code C119604.

This gene is involved in the ubiquitination of target proteins. 